\title{
Joanna Stacewicz-Podlipska
}

Instytut Sztuki Polskiej Akademii Nauk

\section{"CARISSIMO KUREK", CZYLI O BRATERSTWACH AWANGARDY}

Przeciętna publiczność muzealna nie widzi tego, co widzi. Widzi zwykle to, co inni przesądzili, że warto obejrzeć. Tak zwane zwiedzanie stało się dziś lekcją ślepoty, a nie olśnień. Ufamy, że ktoś to wszystko wcześniej za nas przepatrzył, przemyślał, zachwycił się. A my możemy mieć z tym spokój $^{1}$

- tak w pięknej rozmowie z Wiesławem Juszczakiem mówił o współczesnej praktyce „tak zwanego zwiedzania” Dariusz Czaja.

Wystawa Enrico Prampolini. Futuryzm, scenotechnika i teatr polskiej awangardy, którą od 9 czerwca do 8 października 2017 oglądać można było w łódzkim Muzeum Sztuki, skłaniała ku diametralnie innym refleksjom, sprzyjając doświadczeniu o odmiennym ciężarze gatunkowym od tego opisywanego przez Czaję. Zamiast na szkolną swycieczkę zabierała na erudycyjną wyprawę do labiryntu zainteresowań jej kuratora Przemysława Strożka, badacza włoskiego futuryzmu i dziejów jego polskiej recepcji. Pomimo jasno sprecyzowanego celu, jakim było zderzenie twórczości Enrica Prampoliniego z osiągnięciami polskiej awangardy teatralnej, nie była to klasyczna wystawa $\mathrm{z}$ „z tezą", co można było uznać zarówno za niewątpliwą zasługę, jak również za winę kuratora, a osąd w tej sprawie zależał $\mathrm{w}$ głównej mierze od stopnia przygotowania merytorycznego odbiorcy. Wielowątkowa opowieść, jaką snuły eksponaty, zgromadzone tu w bogatym i reprezentatywnym dla tematu wyborze, dla części publiczności zapewne nie dość przystępna, dla innych zaś rewelacyjna, wszystkim bez wyjątku oferowała wysokogatunkowe spotkanie $\mathrm{z}$ awangardą - jedno z najintensywniejszych $\mathrm{w}$ minionym, jubileuszowym roku.

Osią wystawy, co wypunktowane zostało zarówno w jej tytule jak i w topografii, była artystyczna biografia Prampoliniego, którego bogaty dorobek, obejmujący malarstwo, rzeźbę, grafikę, architekturę, choreografię oraz kluczową dla

\footnotetext{
1 D. Czaja, W. Juszczak, Ruiny czasu. Rozmowy o twórczości, Warszawa 2017, s. 195.
} 
ekspozycji „scenotechnikę”, a także działalność teoretyczną,pozostawał w dużym stopniu nieznany polskiej publiczności. Zamysł obszernego przeglądu twórczości artysty, związanego z włoskim futuryzmem aż do lat czterdziestych XX wieku, czynił z łódzkiej wystawy pierwszą tak rozbudowaną prezentację jego prac od czasu ekspozycji Prampolini dal Futurismo all'Informale, którą wiosną 1992, z okazji XII Quadriennale oglądać można było w rzymskim Palazzo delle Esposizioni. W koncepcji Przemysława Strożka monograficzna wystawa twórczości „europejskiego futurysty”, jak w ostatniej monografii określił Prampoliniego Giovanni Lista $^{2}$, zestawiona została w sposób ciekawy, inspirujący i przekonujący z kontekstem polskiej awangardy, która z okazji jubileuszu doczekała się w Łodzi solidnej prezentacji swoich teatralnych osiągnięć. Wybór miejsca dla tak pomyślanej ekspozycji był nieprzypadkowy. To właśnie w łódzkim Muzeum Sztuki przechowywany jest obraz Prampoliniego Tarantella (1920-1922), który, przekazany przez autora grupie a.r. w 1930, wszedł tym samym do jednej z najstarszych kolekcji sztuki awangardowej na świecie.

Jak zadeklarował we wprowadzeniu do katalogu wystawy jej kurator, obraz ten miał być kluczem do zrozumienia koncepcji ekspozycji, która prezentować miała w kilku planach ,zapalne” zagadnienia, sugerowane przez to centralne dzieło. Zgodnie z subiektywnym i skrótowo wymienionym wyborem inspiracji, płynących bezpośrednio od obrazu Tarantella, wystawa koncentrowała się

wokół problemów przedstawienia dynamizmu i symultaniczności w sztuce, fuzji wielu awangardowych stylów i nowych sposobów geometryzacji w malarstwie, następnie wokół futurystycznego tańca i teatru, kwestii mechanizacji ludzkiej postaci w nowej przestrzeni architektonicznej, a także, co znamienne, wokół kontaktów włoskiego futuryzmu z polską awangardą. ${ }^{3}$

Ostatni z sugerowanych czy też wywołanych przez obraz Prampoliniego tematów tworzył zasadnicze spoiwo ekspozycji, która w eksploracji włosko-polskich relacji artystycznych odsłaniała właśnie swoje najbardziej wartościowe i zajmujące treści. Zaprezentowane na wystawie świadectwa tych relacji, angażujące po stronie włoskiej nie tylko skutecznego ambasadora futuryzmu, jakim był Prampolini, ale także Ruggera Vasariego czy samego Marinettiego, po stronie polskiej zaś między innymi Jalu Kurka, Jana Brzękowskiego i Andrzeja Pronaszkę, stanowiły same w sobie bezcenny materiał do badań nad „ponadnarodową siecią sojuszy”4, o której w katalogu wystawy pisała Maria Elena Versari. Zagadnienie międzynarodowych kontaktów pomiędzy przedstawicielami awangardy zaprezentowane zostało jednak w Łodzi w sposób nienachalny, a oddana do użytku zwiedzającego

2 G. Lista, Enrico Prampolini: futurista europeo, Rzym 2013.

3 P. Strożek, Wprowadzenie, [w:] Enrico Prampolini. Futuryzm, scenotechnika iteatr polskiej awangardy, katalog wystawy w Muzeum Sztuki w Łodzi, Łódź 2017, s. 16.

4 M. E. Versari, Do moich przyjaciót ze „Zwrotnicy” - Marinetti, Prampolini i debaty na temat estetyki maszyny w Europie Wschodniej, [w:] Enrico Prampolini. Futuryzm, scenotechnika i teatr polskiej awangardy, op. cit., s. 99. 

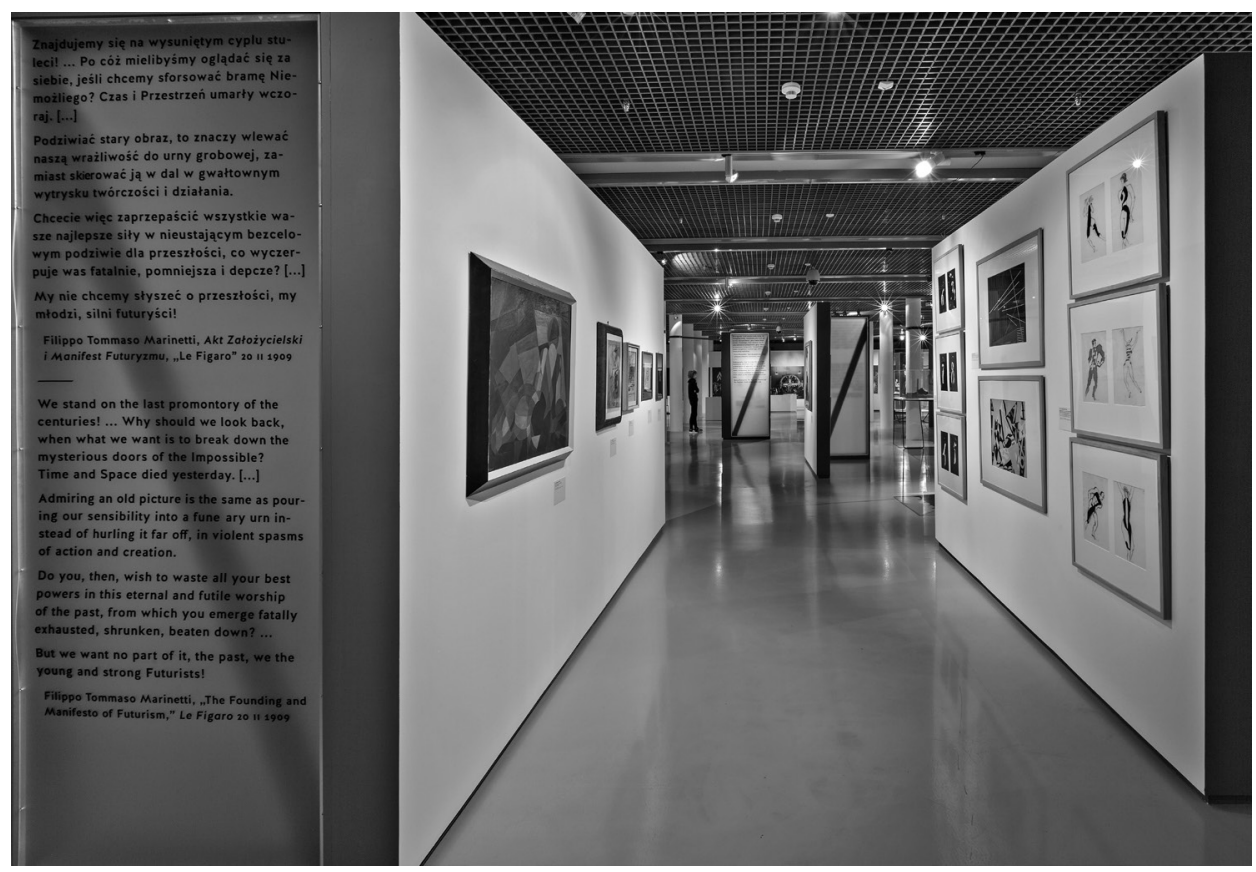

Wystawa Enrico Prampolini. Futuryzm, scenotechnika i teatr polskiej awangardy,

Muzeum Sztuki w Łodzi, 2017

przestrzeń dawała możliwość swobodnej, dostosowanej do stopnia znajomości przedmiotu, eksploracji. Przedsięwzięciu temu sprzyjał niewątpliwie sam teren ekspozycji, który, uniemożliwiając zastosowanie w pełni konsekwentnej, linearnej narracji, skłaniał do opowieści meandrującej i dialogicznej.

W efekcie powstał fascynujący labirynt zaprezentowanych sugestywnie, a niekiedy także ukrytych sprzężeń zwrotnych, zachodzących pomiędzy polską i włoską awangardą lat dwudziestych i trzydziestych XX wieku. Te punkty styku były niekiedy wyraźnie wskazane przez kuratora, innym zaś razem zdawały się być wynikiem przestrzennej ekwilibrystyki, mającej na celu zaprezentowanie w ramach jednej wystawy bogatego dorobku twórczego Prampoliniego oraz równie obszernego tematu polsko-włoskich spotkań artystycznych na gruncie reformy teatralnej, ze szczególnym uwzględnieniem najciekawszych zdobyczy międzynarodowej „scenotechniki”. Na skutek umiejętnej gospodarki niełatwą w gruncie rzeczy przestrzenią ekspozycji powstała w Łodzi zajmująca "strefa dialogu”, oferująca zwiedzającym rozmaite trasy, kreślące każdorazowo nowe ujęcie problemowe i uzupełniające gęstą mapę wpływów, współzależności i powinowactw z wizualną egzemplifikacją nieoczywistych niekiedy korelacji. Przykładem tych ostatnich mogło być chociażby zestawienie, pozostających ze sobą w nieodległym sąsiedztwie kadrów z filmu Antona Guglia Bragagliego Thaïs w opracowaniu 
plastycznym Prampoliniego ze scenografią do Achilleis autorstwa Pronaszki, gdzie geometryczny rytm naprzemiennych pasów wyraźnie dokumentował transnarodową wspólnotę nowej estetyki, sygnalizowaną już w recenzjach z premiery „scen dramatycznych" Wyspiańskiego. ${ }^{5}$

Wystawę można było zwiedzać, kierując się niezobowiązującą, chronologiczną sugestią kuratora. Wówczas trasa rozpoczynała się tradycyjnie, od stacji „Prampolini i futuryzm lat 10.”, by przejść płynnie do części drugiej, dedykowanej sztuce kolejnej dekady wraz z jej przełomowymi eksperymentami „scenotechnicznymi”, a następnie zakończyć zwiedzanie na części trzeciej, poświęconej poszukiwaniom artystycznym Prampoliniego w latach trzydziestych i jego misji upowszechniania „scenotechniki” na forum międzynarodowym. Widz podążający za kuratorskimi wskazówkami, zawartymi w opisach kolejnych dekad artystycznej aktywności Prampoliniego, poruszał się w labiryncie wystawy zgodnie z główną jej osią oraz nanizanymi na tę oś punktami kontaktów polsko-włoskich, tworzących rodzaj przestrzennej mapy. Ale nawet taka, posłuszna koncepcji pomysłodawcy trasa, oferowała ciekawe wycieczki w „boczne uliczki”, w strefę centralną, która zdawała się być poświęcona już w pełni ponadnarodowemu dialogowi form i treści. W całej przestrzeni wystawy dał się wyraźnie odczuć celowy i owocny wysiłek, włożony w uporządkowanie wielowątkowej opowieści i odpowiednie wzajemne pozycjonowanie obu zasadniczych tematów ekspozycji - twórczego dorobku jej głównego bohatera i kontaktów włosko-polskich.

Spomiędzy kilku kluczowych przestrzennych rozstrzygnięć rzucał się w oczy sposób zagospodarowania ścian vis-à-vis oraz owa centralna strefa międzynarodowych spotkań w sztuce. Wokół tej środkowej części odbyć można było konwencjonalny spacer w zgodzie z chronologią, w centrum zaś „kierunek zwiedzania” był zaburzony, a narracja zapętlała się, tworząc multireferencyjną przestrzeń. $\mathrm{Na}$ ścianie naprzeciwko wejścia ulokowane zostały wielkoformatowe reprodukcje, dokumentujące przede wszystkim kamienie milowe polskiej awangardy teatralnej, jakimi były realizacje warszawskiego Teatru im. Bogusławskiego oraz lwowskiego Teatru Wielkiego. Ułożone w taki sposób, by korespondowały także z ramowym układem chronologicznym, akcentowały dyskretną osiowość kompozycji wystawy i znajdowały kontrapunkt w aranżacji ściany przeciwległej, gdzie pokazano bogatą dokumentację inscenizacji Jeńców Marinettiego, wyreżyserowanych w 1933 przez Wacława Radulskiego w Teatrze Wielkim we Lwowie. Sztuka ta, dzięki scenograficznym czy może „scenotechnicznym” zabiegom Pronaszki, które zyskały najwyższe uznanie jej autora, okazała się ,,apogeum eksperymentów teatralnej awangardy w międzywojennej Polsce" niem polsko-włoskich kontaktów artystycznych epoki. W ten sposób prezentacja

5 W. Husarski, „Achillleis” Stanisława Wyspiańskiego w Teatrze im. Bogusławskiego, „Życie Teatru" $1925 \mathrm{nr}$ 48-49.

6 P. Strożek, Marinetti i futuryzm w Polsce 1909-1939. Obecność - kontakty - wydarzenia, Warszawa 2012, s. 201. 
oeuvre Prampoliniego została przestrzennie dopełniona wizualnym reportażem z historycznych osiągnięć polskich reformatorów teatralnych, tworząc ramę dla centralnej strefy międzynarodowego dialogu awangardy. Tam zaś dokumentacja obustronnych starań o przekłady sztuk i wprowadzenie ich na „bratnie” sceny doskonale opowiadała historię przedwojennych polsko-włoskich kontaktów artystycznych. Starania te, daleko wykraczające poza obyczaj „braterskich reklam”, umieszczanych $\mathrm{w}$ awangardowej prasie, unaoczniały wyimki z korespondencji, która, jak w przypadku listu Prampoliniego do Jalu Kurka, rozpoczynającego się od słów „Carissimo Kurek”, dawała świadectwo dużej zażyłości. Opowieść tę uzupełniały makiety Teatru Magnetycznego Prampoliniego oraz Teatru Symultanicznego Andrzeja Pronaszki i Szymona Syrkusa, których wystawowe sąsiedztwo najlepiej ukazywało „układ wzajemnych odniesień o wiele bardziej skomplikowany" niż można było pierwotnie zakładać.

Jerzy Stempowski napisał kiedyś: „terminarz Polski zawsze odbiega od terminarza europejskiego". ${ }^{9}$ Ta konstatacja zdaje się w pewnych kontekstach funkcjonować na prawach aksjomatu, a dyskusji podlegają wówczas jedynie konkretne wyobrażenia na temat naszego usytuowania na osi czasu względem Europy. W przypadku szeroko pojętej polskiej sztuki sądy oscylowały często pomiędzy różnie motywowanym, zaciekłym tropieniem wtórności, a przeciwległym biegunem, równie rozlegle ukorzenionych, pretensji do pierwszeństwa. Nie inaczej było także z osiągnięciami rodzimej awangardy teatralnej, której paradoksem, a zarazem najciekawszym bodaj rysem był, wskazywany już przez Bohdana Korzeniewskiego, mariaż nowoczesności z tradycją. To rozpoznanie znalazło ciekawy refleks także w pismach Pronaszki, który, walcząc zaciekle o to, by „włączyć teatr w nurt nowej sztuki” ${ }^{10}$, a więc dogonić terminarz europejski, wskazywał jednocześnie na źródła reformy tkwiące głęboko tam, gdzie wedle polskiego terminarza rozpoczynało się długie trwanie romantyzmu. Tę diagnozę, charakterystyczną skądinąd dla wielu formistów, egzemplifikował Pronaszko, mianując Mickiewicza ojcem scenicznego faktomontażu, promotorem odnowienia teatru symultanicznego czy wreszcie pionierem walki o nową sztukę, wieszczącym jej nadejście, a więc tym, który „przepowiada możliwość”"11. W tekście Odrodzenie teatru opisywał naturę tych, niekiedy dość pozornych, ambiwalencji: „Dziś przychodzą tylko nowe metody realizacji starej idei, różniącej się jedynie o nacisk innych trochę form rozwijającej się cywilizacji". ${ }^{12}$ Tekst ten rozpoczynał się ważkim i niezwykłym dla awangardysty zdaniem:

Cyt. za: M. E. Versari, op. cit., s. 99.

Ibidem, s. 102.

J. Stempowski, W dolinie Dniestru. Pisma o Ukrainie, Warszawa 2014, s. 199.

A. Pronaszko, Zapiski scenografa, Warszawa 1976, s. 69.

Ibidem, s. 248.

12 Ibidem, s. 230. 
Często się zdarza, że idee, które nam się wydają ostatnim krzykiem dnia dzisiejszego i jako takie spotykają się z zarzutami małej wewnętrznej treści a dużej chęci epatowania, po bliższym poznaniu się z nimi, wykazują posiadanie szeroko rozgałęzionego drzewa genealogicznego sięgającego swymi korzeniami zamierzchłych czasów, a treść ich jest tak ważna, że utrudnia idei zdobycie praw do życia, o które walczy. ${ }^{13}$

Zarysów tego drzewa genealogicznego, szczególnie istotnego, gdy dotykamy tematu rodzimej awangardy, zabrakło na łódzkiej wystawie. Doskonale znane, choć nadal potencjalnie płodne i rezonujące bogatą treścią odwołania do Lekcji XVI Mickiewicza czy idei „Teatru Ogromnego” z całą pewnością stanowiłyby tu naturalne umocowanie dla zaprezentowanych eksponatów. Zaistnienie w przestrzeni wystawy dzieła i myśli Wyspiańskiego - naszego „,największego futurysty" ${ }^{14}$, którego już Wilam Horzyca zaliczał wraz z Marinettim do „twórców wielkiego Dziś" ${ }^{15}$, nie byłoby też z pewnością bezzasadne. Warto jednak zaznaczyć, że rekonstrukcja kolejnych etapów „przecierania drogi”'16, by posłużyć się sformułowaniem Dariusza Kosińskiego, nie wpłynęłaby korzystnie na klarowność formułowanej przez łódzką wystawę ważnej wypowiedzi w sprawie międzynarodowej wspólnoty awangard. Historyczna rekonstrukcja nie była zresztą celem jej kuratora, który zdawał się raczej odtwarzać optykę Marinettiego, wołającego buńczucznie: „Znajdujemy się na wysuniętym cyplu stuleci!’"17. Zaprezentował więc „przekrój poprzeczny” przez „chwilę”, w której w oddalonych od siebie częściach świata artyści stawiali sobie te same pytania i formułowali zbliżone odpowiedzi. Przemysław Strożek nie próbował ustalać stopnia pokrewieństwa i rodzaju zależności, występujących pomiędzy zaprezentowanymi na wystawie eksponatami, nie wskazywał ojców oraz synów i nie prowadził ,wpływologicznych” analiz. Nad wystawą unosił się raczej konsyliacyjny duch, rodem z rozrachunków z formizmem, jakie prowadził swego czasu August Zamoyski:

Grzyby rosną i dojrzewają równocześnie w całym lesie po ciepłym deszczu, a maślak nic nie wie o kozaku, jak i rydz o robiącej dużo kurzu purchawce. ${ }^{18}$

Kiedy już wyrosną, zdawało się słyszeć na łódzkiej wystawie, mogą niekiedy zaskakiwać swoim podobieństwem.

Ideą Przemysława Strożka było, co oczywiste, przeprowadzenie dowodu na owocne, prawdziwie partnerskie, międzynarodowe kontakty i artystyczną jedność awangardy. Na temat transgranicznej ,grzybni”, która mogła ją zrodzić, kurator dyskretnie milczał, pozostając skądinąd w pełnej zgodzie z poetyką maszyny, robiącej ,szybki rozrachunek pomiędzy umarłymi problemami życia, a tymi, które

\footnotetext{
13 Ibidem.

14 I. Fik, Dwadzieścia lat literatury polskiej (1918-1938), Kraków 1949, s. 51-52.

15 W. Horzyca, Wyspiański i Marinetti, ,Scena Lwowska” 1932/33 nr 5, s. 120.

16 D. Kosiński, Teatra polskie. Historie, Warszawa 2010, s. 345.

17 F. T. Marinetti, Akt Założycielski i Manifest Futuryzmu, „Le Figaro” 20 II 1909.

18 A. Zamoyski, Jak $i$ dlaczego wyrostem z formizmu, „Poezja” 1968 nr 1-2, s. 23.
} 
pozostają". ${ }^{19}$ Dla zwiedzającego wystawę uderzające mogło być właśnie to, jak wiele problemów, z którymi mierzyli się sto lat temu koryfeusze awangardy, pozostało do dziś nierozwiązanych. Ich historię opowiadały eksponaty, wciąż odkrywcze i niezwykłe, jak chociażby znakomity projekt Teatru Ruchomego Pronaszki i Stefana Bryły. Wystawa w Muzeum Sztuki, relacjonując kolejne etapy wielkiej walki, jaką promotorzy „scenotechniki” stoczyli z upiorem sceny pudełkowej i przynależnej jej „oprawy dekoracyjnej”, opowiadała historię rebelii nie w pełni udanej, niedokończonej, a niekiedy przeciwskutecznej.

Czy naprawdę pozostać mamy po wieki wieków w tych okropieństwach i nie zdobędziemy się nigdy na zbiorowy wysiłek stworzenia nowej, racjonalnej, współczesnej sputnikom przestrzeni teatralnej? Wygląda na to, że nigdy ${ }^{20}$

- przewidywał pod koniec życia Pronaszko. Współczesna sputnikom przestrzeń teatralna nie spełniła wszystkich snów awangardy, a jej progresywny mit w lustrzanym gabinecie ponowoczesności, spękany i zmultiplikowany, przestraszył się sam siebie.

„Współczesność”, a więc czas, który sobie przywłaszczamy, określając go jako „nasz”, okazuje się czymś stojącym na antypodach „teraźniejszości”, która istnieje poza tętnem zegarów i spadającymi kartkami kalendarzy ${ }^{21}$

- mówił Wiesław Juszczak w przywoływanej wyżej rozmowie z Dariuszem Czają. Chcąc tę ulotną „,współczesność” sprzed wieku udokumentować i odtworzyć, Przemysław Strożek, z typową dla siebie inwentaryzatorską pasją, znaną z książki Marinetti i futuryzm w Polsce 1909-1939. Obecność - kontakty - wydarzenia, wynotował drobiazgowo wszystkie punkty styku polskiej i włoskiej awangardy, odtwarzając z pietyzmem czasoprzestrzeń historycznych spotkań, ich okoliczności, motywy, reperkusje, spodziewane efekty i rzeczywiste konsekwencje. Starając się uporządkować i uprzystępnić wartki nurt zdarzeń, będących skutkiem usilnych starań wielu ludzi, a niejednokrotnie także dziełem przypadku, zawiesił na osiach czasu punkty wzmożonych kontaktów, wspólnych przełomowych realizacji lub projektów. Tym sposobem powstała doskonale zinwentaryzowana baza zdarzeń, planów i śladów relacji międzyludzkich, która, choć ustrukturyzowana, pozostawiała możliwość samodzielnego wyciągnięcia wniosków. Wnioski te, zależnie od merytorycznego uposażenia widzów i szlaków wybranych przez nich w przestrzeni wystawy, oscylować mogły pomiędzy podstawową wiedzą poprzez uszczegółowioną informację, na postulowanej przez Czaję „lekcji olśnienia” kończąc. Każda zaś z „lekcji”, jaką można było odbyć, znajdowała stosowne uzupełnienie w katalogu wystawy, który, będąc udanym połączeniem niezwykle pięknie wydanego albumu z istotnym, naukowym wielogłosem, jest z pewnością ważną

\footnotetext{
19 A. Pronaszko, op. cit., s. 228.

20 Ibidem, s. 268.

21 D. Czaja, W. Juszczak, op. cit., s. 210.
} 
pozycją w bibliografii wszystkich tematów ekspozycji - futuryzmu włoskiego, międzynarodowej „scenotechniki” i polskiej awangardy teatralnej. Ta ostatnia znalazła w przychylnej sobie Łodzi szczególnego sojusznika. Trawestując słynne słowa Marinettiego o „Zwrotnicy”, która zamieszkiwana miała być przez „świętość", stwierdzić można, że wystawa w łódzkim Muzeum Sztuki była jednym z niewielu miejsc, które w minionym, jubileuszowym roku zamieszkiwane były przez awangardę. 